\title{
Os Manuais de Direito Romano na Formação do Jurisconsulto Clóvis Beviláqua
}

\author{
The Manuals of Roman Law in the Formation of the Jurist Clóvis Beviláqua
}

Rose Dayanne Santos de Brito*

\section{REFERÊNCIA}

BRITO, Rose Dayanne Santos de. Os Manuais de Direito Romano na Formação do Jurisconsulto Clóvis Beviláqua. Revista de Direito da UFRGS, Porto Alegre, n. 46, p. 146-160, ago. 2021. DOI: https://doi.org/10.22456/01046594.108737

\section{RESUMO}

O artigo tem o objetivo de investigar a influência dos manuais de direito romano na formação intelectual de Clóvis Beviláqua. A importância da pesquisa é identificar as correntes teóricas que contribuíram para a formação do pensamento de Beviláqua, autor do Código Civil de 1916. Para tanto, o presente artigo segue os rastros dos manuais e os autores estrangeiros lidos por Beviláqua, assim como as lições do seu professor de direito romano e o contexto intelectual da Faculdade de Direito do Recife. Trata-se, portanto, de um exercício de história do direito que pretende demonstrar a sintonia entre a produção e o pensamento deste autor com a época em que viveu e o processo de construção da cultura jurídica brasileira.

\section{PALAVRAS-CHAVE}

Clóvis Beviláqua. Direito Romano. Manuais. Cultura jurídica. Brasil.

\begin{abstract}
The article aims to investigate the influence of Roman law manuals on the intellectual formation of Clovis Beviláqua. The importance of the research is to identify the theoretical currents that contributed to the formation of Beviláqua's thought, as he is the author of the Civil Code of 1916.Therefore, this article follows the traces of the manuals and foreign authors read by Beviláqua, as well as the lessons of his professor of Roman law and the intellectual context of the Faculty of Law of Recife. Thus, it is an exercise in the history of law that intends to demonstrate the harmony between the production and the thought of this author with the time in which he lived and the process of construction of the Brazilian legal culture.
\end{abstract}

\section{KEYWORDS}

Clóvis Beviláqua. Roman law. Manuals. Legal culture. Brazil.

\section{SUMÁRIO}

1. Introdução. 2. Os manuais nos cursos jurídicos do Brasil Império. 3. A formação jurídica de Clóvis Beviláqua.

4. O direito romano e a filosofia em Clóvis Beviláqua. 5. Conclusão. Referências. Dados da publicação.

\section{INTRODUÇÃO}

Clóvis Beviláqua inicia o curso de direito na Faculdade de Recife em 1878, ano em que conhece João José Pinto Junior professor catedrático de direito romano. Sobre este professor, Clóvis relata que embora ele tivesse apenas 56 anos de idade, ele havia perdido o

\footnotetext{
* Doutora em Direito pela Università degli Studi di Roma Tor Vergata, Itália. Mestra em Direito pela Universidade Federal de Santa Catarina. Graduada em Direito na Universidade Federal de Pernambuco, com período cursado na Alemanha (Eberhard Karls Universität Tübingen).
} 
brilho e o interesse que demonstrava ter no início da carreira. ${ }^{1}$ Apesar disso, reconhece que esse professor sempre cumpriu com os deveres acadêmicos e que o livro Curso elementar de direito romano era um bom manual que servia de introdução as Institutas, pois tinha precisão e clareza nos argumentos.

No prefácio do livro, que correspondia a aula inaugural do curso, João José Pinto Junior destacava para seus alunos a importância do estudo do direito romano. No decorrer do texto, ele afirmava: "eu continuo a considerar o Direito Romano como a mais pura fonte do Direito Civil moderno"2. O conhecimento do direito romano na formação dos juristas seria fundamental, tanto nos países que já tinham uma Codificação, a exemplo da França e da Itália, como também nos países que não havia um Código Civil, como era o caso do Brasil.

Segundo Pinto Júnior, a falta de uma codificação tornava a legislação brasileira caótica e fragmentada. Porém, o conhecimento do direito romano servia como direito subsidiário, para casos omissos conforme dispositivo das Ordenações (Livro 3, Título 64). Ainda acrescentava que essa regra havia sido corroborada pela Lei 18 de Agosto de 1789 que especificava os casos em que o direito romano deveria ser aplicado na prática jurídica brasileira.

O compêndio utilizado na Faculdade de Direito do Recife era as Institutiones Iuris Romani Privati de Warnkoenig. Durante a pesquisa para elaboração deste artigo, a obra foi encontrada na Biblioteca da Faculdade de Recife apenas a versão em latim, não havendo registro da tradução para o português de Chaves de Mello. É muito provável que Clóvis Beviláqua tenha manuseado este compêndio de Warnkoernig, como aluno e depois como bibliotecário. Na biografia escrita por Silvio Meira, há menção que o romanismo de Clóvis Beviláqua provinha desde a juventude, em virtude do apego pelo interesse literário, isso não foi possível de ser comprovado. Um fato verificável é que "um dos aspectos mais importantes da obra de Clóvis Beviláqua, e que não é estudado integralmente é aquele relativo à influencia do direito romano sobre toda a sua produção jurídica e filosófica."3

Sobre o ensino do direito romano na Faculdade de Direito do Recife, o professor de Clóvis Beviláqua reiterava aos alunos a necessidade de estudar não apenas as Institutas, mas a importância de ter uma formação geral sobre a legislação e a história de Roma. Pinto Júnior aconselhava os estudantes a acompanhar as obras dos romanistas modernos e afirmava que

\footnotetext{
${ }^{1}$ BEVILÁQUA, Clóvis. História da Faculdade de Direito do Recife. Rio de Janeiro, Francisco Alves, 1927, vol. II, p. 57.

${ }^{2}$ PINTO JUNIOR, João José. Curso elementar de direito romano. Recife, Tipografia Econômica, 1888, p. IX.

${ }^{3}$ MEIRA, Silvio. Clóvia Beviláqua. Sua Vida. Sua Obra. Fortaleza: Edições Universidade Federal do Ceará, 1990, p. 346.
} 
"todos os dias surgem, sobretudo na Alemanha, jurisconsultos notáveis, que, como Ihering, iluminarão os recessos mais sombrios do direito romano."4

A partir do relato acima é possível verificar como os autores alemães tinham uma forte influência na Faculdade de Direito do Recife, em especial, na disciplina de direito romano. A hipótese a ser comprovada neste artigo é a influência dos manuais e o ambiente acadêmico na obra de Clóvis Beviláqua. Conseqüentemente, as releituras modernizantes sobre institutos do direito romano, em especial, da tradição germânica na sua teoria jurídica

Conforme salienta Pietro Costa, o historiador do direito deve compreender que "o texto não encerra um e somente um significado. O texto é muito mais um cruzamento de possibilidades semânticas, tão mais amplo quanto mais sua tessitura é rica e complexa."5

\section{OS MANUAIS NOS CURSOS JURÍDICOS DO BRASIL IMPÉRIO}

Um ponto relevante sobre a inserção da disciplina de direito romano no Brasil Império é a ênfase dada ao direito privado romano em detrimento do direito público romano. O manual de Pinto Júnior alertava os estudantes que "os grandes elogios que tem sido feitos ao direito romano, são aplicáveis somente ao direito romano privado; não são extensivos ao Direito que regia o statum rei romanae." $\mathrm{O}$ professor de Beviláqua acrescentava que as instituições políticas de Roma eram diferentes da modernidade, logo não havia sentido estudá-las. Nesse momento, cita Calixte Accarias, o manual Précis de droit romain (1882) e reafirma que o direito romano público e o criminal não se aplicaria mais, apenas o direito privado ${ }^{7}$. Este argumento nos dias atuais não se demonstra verdadeiro, uma vez que o estudo do direito público romano permite chaves de leituras importantes para compreender o mundo jurídico de hoje, conforme se verifica na obra atualizada do romanista Pierangelo Catalano ${ }^{8}$.

Entre os autores romanistas alemães e franceses mais indicados e lidos na Faculdade de Direito do Recife, destaca-se: Ihering, Ortolon, Savigny, Salivas e Bellan, Mackeldey, Van

\footnotetext{
${ }^{4}$ PINTO JUNIOR, João José. Curso elementar de direito romano. Recife, Tipografia Econômica, 1888, p. XII.

${ }^{5}$ COSTA, Pietro. Passado: dilemas e instrumentos da historiografia. Revista da Faculdade de Direito UFPR, n. 47. Curitiba: UFPR, 2008, p. 23.

${ }^{6}$ PINTO JUNIOR, João José. Curso elementar de direito romano. Recife, Tipografia Econômica, 1888, p. IX.

${ }^{7}$ Esta visão não era particular de Pinto Junior, o professor Netto Campello que assumiu a cátedra de direito romano em seguida também no seu manual reproduzia a mesma concepção negativa sobre o direito público romano. Entendia que "o direito público romano não pode servir de base ao direito publico moderno, porquanto a organização dos Estados atuais não comporta a estreiteza da sociedade antiga.” In: CAMPELLO, Manoel Netto Carneiro. Direito Romano. Preleções Expedidas em aula. Rio de Janeiro, V. 1, 1929, p. 43.

${ }^{8}$ CATALANO, Pierangelo. Diritto e persone. Studi su origine e attualità del sistema romano. G. Giappichelli Editore, Torino, 1990.
} 
Wetter e Warnkoening. Nas aulas de Pinto Júnior, o compêndio de Calixte Accarias era de forma repetitiva referido para os estudantes, em especial, quando tratava da classificação em direito das pessoas, coisas e ações. Sobre esta temática, acrescentava que as pessoas são independentes das relações com as coisas, inclusive, pelos múltiplos papéis que podem representar na sociedade, como escravo ou liberto. Pinto Júnior não aprofundava o debate sobre a natureza jurídica do escravo romano, se era pessoa ou coisa, mas através da compreensão ampla de sua obra, o escravo no direito romano deveria ser considerado pessoa. O aluno Clóvis Bevilaqua, anos depois, apresentaria uma perspectiva diversa no texto Sobre o valor jurídico do escravo romano divergindo, nesse aspecto, do seu professor de direito romano.

As obras nacionais sobre direito romano que mais se destacaram na época de formação de Clóvis Beviláqua em Recife, foram: Elementos de Direito Romano do professor Barros Guimarães, Curso Elementar de Direito Romano de Pinto Júnior, Pontos de Direito Romano de José Soriano de Souza e as Preleções de Direito Romano de Neto Campello. Em São Paulo, os livros que mais se destacavam eram as Preleções Completas de Direito Romano do professor Dutra Rodrigues e o Curso elementar de Direito Romano de Reinaldo Porchat. Estes livros refletiam o programa oficial adotado pelos professores na disciplina que ministrava. A presente pesquisa constatou nas fontes históricas que havia diálogos e trocas de correspondências entre os professores de direito romano do Recife e de São Paulo na época do Império.

O livro de Netto Campello, professor da Faculdade de Direito do Recife, elogiado no jornal da época por Clóvis Beviláqua, apresentava uma maior atenção às fontes primárias do direito romano. O livro intitulado Direito Romano (Preleções expendidas em aula) eram as notas taquigráficas do estudante do primeiro ano Theodoro Tavares Cordeiro Campos. Ele inicia o segundo volume do livro com a afirmação de que os romanos não conheciam o conceito genérico para designar o direito das coisas em contraposição ao jura personarum. Apenas nas Institutas de Justiniano é que o termo se cristalizou. Ao tratar da concepção de coisa no direito romano arcaico, Netto Campello menciona as várias acepções do termo. Afirma ele que, os romanos compreendiam como coisa, "não só os corpos desprovidos de razão, mas também certos homens, como os escravos, privados de toda capacidade civil". 9

Desse trecho, pode-se verificar que Netto Campello fazia parte dos juristas brasileiros que entendiam que o escravo era coisa, não pessoa. Para defender esta visão, argumentava com base em uma visão equivocada do direito romano. É possível verificar também a visão

${ }^{9}$ CAMPELlO, Manoel Netto Carneiro.Direito Romano. Preleções Expedidas em aula. Rio de Janeiro, Vol 2, 1929, p. 17-18. 
modernizante na explicação de Campello, pois o termo "capacidade civil" era um reflexo das codificações burguesas no seu pensamento e não um conceito do direito romano arcaico. Neste livro, Campello conclui que as coisas são, para os romanos, objeto do direito e da pessoa. Para tanto fazia referência a Gaio para validar o seu ponto de vista: omne jus quo utimur, vel ad personas pertinet, vel ad res, vel ad actiones (Todo o direito que usamos, respeita ou às pessoas, ou às coisas, ou às ações).

Este fragmento das Institutas, assim com a definição do conceito de direito romano desenvolvida por Netto Campello demonstra as concepções desenvolvidas durante a cultura jurídica do Império. Há poucas referências a doutrina e aos manuais de autores italianos e, quando citados, são para demonstrar divergência na linha de pensamento. Entre os italianos que são citados, estão Pietro Coglio e seu livro Storia del Diritto Privato Romano e Francesco de Filippis e sua obra Corso completo de diritto civile italiano comparato.

Um aspecto importante do livro de Netto Campello é um capítulo específico sobre o tema da escravidão. O que demonstra que o professor de Direito Romano se interessou pela temática a ponto de elaborar um estudo específico sobre o assunto. $\mathrm{O}$ capítulo foi intitulado "Origem da escravidão, condições jurídicas do escravo, extinção da escravidão". Alguns traços deste estudo serão apontados para verificar se há conexão com o texto de Clóvis BevilÁqua Sobre o valor jurídico do escravo romano, escritos anos depois.

Segundo Netto Campello, a origem da escravidão em Roma foi a guerra. Tanto a guerra como o comércio fizeram afluir escravos na região, acrescenta que o comércio contribuiu para alimentar a escravidão. É possível verificar que a concepção de escravidão de Netto Campello é profundamente influenciada pelo período temporal do império em Roma e pela visão de Justiniano. No livro La schiavitù nell'età giustinianea, Melluso conclui que Giustiniano "em particular, no que diz respeito a escravidão afirma que foi introduzida pela guerra e acrescenta que os homens, ao conseguir por um tempo a liberdade e a ingenuidade, vêem então restituídos a natura." ${ }^{10}$ Da mesma forma que Justiniano ao tratar dos liberi naturales opõe a escravidão ao direito natural e trata da artificialidade deste instituto, Netto Campello entende que a escravidão corresponderia a uma instituição do direito das gentes, isto é, não pertencente a concepção do direito natural romano.

Outra marca da influência de Justiniano na obra de Netto Campello é a utilização do livro Explication Méthodique des Institutes de Justinien de Georges Bonjean publicado no ano

\footnotetext{
${ }^{10}$ MELLUSO, M. La schiavitù nell'età giustinianea. Disciplina giuridica e rilevanza sociale, Paris 2000, Presses Universitaires Franc-Comtoises, 2000, p. 287, tradução livre.
} 
de 1878. Existe referência explícita a este livro ao ponto de Netto Campello afirmar: “interrogam Lariche e Bonjean: o escravo é pessoa? Sim, respondem eles, porque o escravo pode figurar como intermediário de seu senhor em atos jurídicos, contratar uma obrigação natural, etc." ${ }^{11}$ Um ponto a ser investigado é que a pergunta se o escravo é pessoa ou coisa não apenas aparece no texto de Clovis Bevilaqua Sobre o valor jurídico do escravo romano (1886), mas é central na argumentação de Netto Campello, o que sugere que este dilema foi significativo na cultura jurídica brasileira do período.

Além dos autores alemães, a doutrina francesa influenciou os professores de direito romano da Faculdade de Direito do Recife, tanto que Netto Campello mencionava outro autor da doutrina jurídica francesa para argumentar seu ponto de vista sobre escravidão. Desta vez, a referência era a Charles Demangeat, que foi professor catedrático de direito romano na da Faculdade de Direito de Paris. O professor brasileiro parafraseava e transcrevia trechos do livro Cours elementaire de droit romain. Para desenvolver o argumento e a polêmica no Brasil, ele exaltava a pergunta de Demangeat: O escravo é realmente uma pessoa? Não é antes uma coisa?

Com base na pergunta acima, Netto Campello corroborava a posição do autor francês que relativizava a literalidade dos textos romanos, pois em certos fragmentos realmente o escravo aparece como coisa ${ }^{12}$, ora como pessoa. Apesar dessa aparente ambigüidade, Netto Campello, nos rastros de Demangeat, conclui que pelo fato de o "escravo poder ser sujeito de direito ou parte num ato, segue-se necessariamente que ele é pessoa. Du Caurroy e outros romanistas pensam do mesmo modo." ${ }^{13} \mathrm{O}$ professor brasileiro reconhece, portanto, que a solução para este dilema era o ponto de vista dos romanistas franceses que tinham por fundamento relativizar a dicotomia de conceber o escravo como pessoa ou coisa. No texto, há referência a outro professor francês de direito romano, Adolphe Marie Du Caurroy de La Croix. Seu celebre livro Institutes de Justinien, traduzido por Jacques Cujas em 1813 não foi encontrado na Faculdade de Direito Recife.

\section{A FORMAÇÃo JURÍDICA DE CLÓVIS BEVILÁQUA}

\footnotetext{
${ }^{11}$ CAMPELLO, Manoel Netto Carneiro. Direito Romano. Preleções Expedidas em aula. Rio de Janeiro, Vol 2, 1929, p. 204.

${ }^{12}$ Netto Campello não menciona o livro de Charles Demangeat que utiliza para construir seu ponto de vista. Porém, a presente pesquisa verificou várias paráfrases ao Courselementaire de droitromain. Dentre eles, é reiterado pelo professor brasileiro que: "chez lês romains, l'esclavelui-mème est considere comme une chose, em CE sensqu'ikpeutêtrel'objetdudroit de propriété ou dudroit d usufrut. In: DEMANGEAT, M. Charles. Coursélémentaraire de droit romain. Seconde edition. Paris, MarescoAiné, Libraire-editeur, 1866, p. 143.

${ }^{13}$ CAMPELlO, Manoel Netto Carneiro. Direito Romano. Preleções Expedidas em aula. Rio de Janeiro, Vol 2 , 1929, p. 205.
} 
Clóvis se tornou bacharel em 1882, ano em que Tobias Barreto ingressava como professor na Faculdade de Direito do Recife, após concurso polêmico. Dos colegas de turma de Beviláqua e contemporâneos de Faculdade, muitos se tornaram figuras importantes e políticos da época. Alfredo Moreira de Barros Oliveira Lima, por exemplo, transferiu-se para São Paulo, onde assumiu tempo depois o cargo de professor da Faculdade de Direito. Nesse período, a cidade do Recife era cosmopolita e a Faculdade um ambiente que atraia jovens e intelectuais de todo o Brasil para o curso de ciências jurídicas.

A turma de Beviláqua formou setenta e quatro bacharéis, esses jovens vinham do Pará, Maranhão, Piauí, Ceará, Paraíba, Pernambuco, Alagoas, Sergipe, Bahia, Rio de Janeiro, Mato Grosso e Paraná, o que demonstrava sua importância no cenário brasileiro. "Recebendo o grau de bacharel em ciências jurídicas esses jovens tinham a sua frente muitos caminhos a seguir. Clóvis, homem de gabinete, retraído e introvertido, não tentaria a advocacia militante, a luta do foro, o contato com cliente e com os serventuários da justiça." 14 Ao terminar a Faculdade, Clóvis não segue carreira em Recife, nem em São Paulo. O destino escolhido é seu Estado de origem, o Ceará, onde lhe foi negado o cargo de Promotoria, apesar de todos os esforços para obtenção do cargo ${ }^{15}$.

Ele regressa ao Recife em 1884 onde é nomeado bibliotecário da Faculdade de Direito. Em sua biografia, fica evidenciado a importância deste cargo para aprofundar a leitura de obras raras e da doutrina estrangeira. No exercício do cargo, "era pago para isso. Não descurava de suas obrigações funcionais, mas, ao mesmo tempo, fazia o que lhe era de maior grado: lia. Lia e escrevia. Traduzia. Seus trabalhos, daí por diante, tornaram-se mais vigorosos."16

No ano de 1889, surgiu uma vaga para ministrar a disciplina de Filosofia no Curso Anexo da Faculdade, participou do concurso e foi o primeiro lugar com a tese sobre o conceito antigo e moderno de metafísica. Nos escritos posteriores destacou o caráter essencial da filosofia fundamentada na universalidade. A preocupação em acompanhar as datas nesta pesquisa é importante, pois fica descartada a hipótese de que o texto Sobre o Valor jurídico do escravo romano, escrito em 1886, foi elaborado com a intenção de Clóvis promover sua

\footnotetext{
${ }^{14}$ MEIRA Silvio. Clóvis Beviláqua. Sua Vida. Sua Obra. Fortaleza: Edições Universidade Federal do Ceará, 1990, p. 68.

${ }^{15}$ Pra mais informações sobre a vida pessoal de Clóvis Beviláqua e os dados cronológicos de sua extensa obra, ver: OLIVEIRA, João Gualberto.Clóvis Centenario. São Paulo: Bentivegna, 1961.

${ }^{16}$ MEIRA,, Silvio.Clóvis Beviláqua. Sua Vida. Sua Obra. Fortaleza: Edições Universidade Federal do Ceará, 1990, p. 94.
} 
candidatura no concurso para professor do curso jurídico. O mais provável é que a repercussão do tema na cultura jurídica e política do Brasil da época tenham despertado o interesse também em Beviláqua em dissertar sobre o assunto, conforme ele mesmo relata anos depois.

Em 1891, tornou-se professor da Faculdade de Direito do Recife em uma nova disciplina que acabara de surgir e tinha sido inserida no último ano do curso. A disciplina era Legislação Comparada sobre direito Privado que segundo ele, o conteúdo era destinado "a comparação, ao confronto, ao cotejo da legislação brasileira, com as de outros países, na sua forma vigorante, e, acessoriamente, com as fases anteriores do seu desenvolvimento." ${ }^{17}$ Clóvis permanecerá até 1906 em Recife depois seguirá para o Rio de Janeiro e assumirá o cargo de Consultor Jurídico do Ministério das Relações Exteriores. O período em que foi estudante, bibliotecário e professor na Faculdade de Direito do Recife influenciou sua formação intelectual e refletiu nas suas obras.

José Augusto, estudante de Clóvis Beviláqua e com quem conviveu por mais de quarenta anos, relatou que desde a época em que Clóvis foi estudante da Faculdade de Direito do Recife, havia sido um ávido leitor. Entre os principais autores que havia se dedicado a ler, Clóvis mencionava: na Literatura, os autores brasileiros como José de Alencar e Sílvio Romero e os europeus Teine e Emile Zola. Na filosofia, havia se dedicado aos livros de Litré, Augusto Comte, Herbert Spencer e Haeckel. Na área jurídica, menciona Ihering, Post, Savigny, Glasson e Tobias Barreto.

Há nos escritos de Clóvis referência e admiração a Tobias Barreto de Meneses ${ }^{18}$, o que sugere influência direta em suas obras. Clóvis destacava, sobretudo, o papel divulgador destes autores em teorias ainda pouco divulgadas no Brasil:

o monismo era mal conhecido entre nós, embora os livros de Haeckel já circulassem entre os jovens. Ninguém, porém, tinha ainda pensado que desta teoria poderia surgir uma concepção geral do fenômeno jurídico. Foi este aporte de Tobias Barreto que utilizou os trabalhos de Haeckel e de Noiré, elogiados pelo criticismo kantiano,remodelando as doutrinas de Ihering e de Hermannn Post, a partir da sua inteligência superior e original. ${ }^{19}$

\footnotetext{
17 BEVILÁQUA, Clóvis. Resumo das Licçoes de Legislação Comparada sobre o Direito Privado. Recife: Typographia de F. P. Boulitreau, 1893.

${ }^{18} \mathrm{Na}$ pesquisa detalhada realizada por Mario Losano, é possível verificar que "l'insegnamentoallafacoltàdi Recife segnalaterzaedultima fase dellavita sia física siaculturaledi Tobias Barreto. Dal 1882 all'anno della sua morte, nel 1889, non vi sono fatti biograficamente rilevanti da registrare [..] è interessante ricordare qui il volume Studi tedeschi, che nel 1883 raccoglie i migliori saggi pubblicati pochi anni prima” IN: LOSANO, Mario G. La scuola di Recife e l'influenza tedesca sul diritto brasiliano. In: Giovanni Tarello. (org) Materiali per uma storiadella cultura giuridica. Vol. IV, Mulino, 1974, p. 349-353.

${ }^{19}$ BEVILÁQUA, Clóvis. Juristas philosophos. Imprenta: Bahia, Livraria Magalhães, 1897, p. 23.
} 
Tobias Barreto não apenas foi um mentor intelectual do movimento da Escola do Recife, foi o grande difusor do positivismo na Faculdade de Direito, marcado pelas leituras de Herbert Spencer. O evolucionismo foi um ponto em comum entre Tobias Barreto e Clóvis Beviláqua. Tanto que ele reconhece que quase todos no Recife escreviam dominados pela orientação positivista, foi nesse sentido que escreveu o texto A Philosofia Positiva no Brazil que contextualiza este período e a circulação das idéias. Em um relato pessoal, Clóvis reconhece: “devo a Tobias Barreto o inestimável serviço de me ter aberto a inteligência para o Direito [...]. Incitado pelo ensino de Tobias e guiado por Ihering, vi o Direito à luz da filosofia, da sociologia e da história." 20

Entre os livros de Ihering mais citados por Clóvis estão: $O$ Espírito do direito romano, A Finalidade do Direito, A Luta pelo Direito. As obras de Hermann Post que mais exerceram influência sobre ele foram: Jurisprudência ethnologica e Fundamentos do direito. Em comparação com as obras de Savigny, Clóvis entendia que os livros de Ihering não possuíam um caráter prático e nem a profundidade que os Tratados de Savigny, mas reconhecia que os livros de Ihering eram os "consultados geralmente por todos aqueles que desejam possuir uma exata noção dos institutos romanos." ${ }^{21}$ Neste fragmento, estão expressas as lentes utilizadas por Clóvis Beviláqua para compreender os institutos do direito romano. A influência alemã era marcante e ainda contava com os desvios das traduções, mencionadas por Clóvis, de certo modo um facilitador das idéias de Ihering em vários países. Ele mencionava, por exemplo, a circulação dos livros de Ihering em traduções para o francês, italiano, espanhol, grego, japonês, húngaro e português.

As leituras de obras estrangeiras por Clóvis Beviláqua não foram recepcionadas de forma acrítica, pelo contrário, ao ter contato com a doutrina de Gustavo Le Bon, ele elaborou várias discordâncias em relação ao pensador francês. O fundamento central de superioridade das raças de sua teoria é criticado por Beviláqua. Além da influência brasileira de Tobias Barreto, Clóvis Beviláqua foi leitor da produção de Silvio Romero, tanto das criticas literárias como da produção sociológica. Bacharel em direito pela Faculdade de Direito do Recife em 1873, quase uma década antes de Beviláqua, Silvio Romero também criticava a corrente francesa que utilizava o conceito de raça e fazia uma confusão entre o sentido antropológico e sociológico do termo.

\footnotetext{
${ }^{20}$ MEIRA, Silvio. Clóvis Beviláqua. Sua Vida. Sua Obra. Fortaleza: Edições Universidade Federal do Ceará, 1990 , p. 66.

${ }^{21}$ BEVILÁQUA, Clóvis. Juristas philosophos. Imprenta: Bahia, Livraria Magalhães, 1897, p.62.
} 
O conceito de raça no final do século XIX foi central na sociologia européia, Silvio Romero influenciado pela Escola de Le Play escreveu sobre a formação da sociedade brasileira a partir da ideia de inferioridade das raças. Na obra O Brasil Social e outros estudos sociológicos, Silvio Romero relata a precária condição dos escravos após a abolição da escravatura e o poder das oligarquias locais na política brasileira. Os ex-escravos continuavam marginalizados, invisíveis às políticas sociais e ao direito.

A Proclamação da República, que ocorreu um ano após a proibição da escravidão, pouco havia mudado a vida da população brasileira, nesse sentido afirmava Romero: "o Brasil é fundamentalmente isto mesmo, sendo apenas a grande novidade a incorporação dos exescravos nessa enorme massa de população proletária, quer dos campos, quer das grandes povoações." ${ }^{22}$ Clóvis Beviláqua mencionava Silvio Romero como um dos mais ilustrados da geração da Escola do Recife.

\section{O DIREITO ROMANO E A FILOSOFIAEM CLÓVIS BEVILÁQUA}

Na obra de Silvio Romero, o direito estaria interligado às questões da sociologia, para Clóvis Beviláqua o direito se aproximava da filosofia. A reflexão filosófica de Beviláqua também incluiu o direito romano, isso fica explícito no texto que escreve sobre Cícero. Ele reitera o entendimento de Ihering de que a jurisprudência foi a principal filosofia dos romanos.

Uma filosofia prática que se distanciava das divagações abstratas. Um modelo de jurista-filósofo a ser seguido, Cícero é visto como um dos mais brilhantes pensadores da antiguidade. Compreendia que "os grandes jurisconsultos clássicos Gaio, Papiniano, Ulpiano, Paulo e Modestino são estoicos. Cicero foi eclético, um simples diletante, embora dotado de qualidades superiores e profundamente instruído." ${ }^{23}$ Clóvis faz menção às inúmeras obras de Cícero, dentre elas, De republica, De legibus, De officiis que contribuem para uma compreensão sobre o direito. Cicero enaltecia a política e a oratória de Quinto Mucio, pois este havia consolidado uma mudança na jurisprudência da época que deixou de ser focada apenas na interpretação da legislação decemviral para enfatizar um aspecto prático do direito e uma elaboração científica.

Segundo Beviláqua, Cicero adentrou no direito romano pelo caminho da filosofia e influenciou o pensamento jurídico romano. De Republica é um tratado de direito público que

${ }^{22}$ ROMERO, Silvio. O Brasil social e outros estudos sociológicos. Brasília: Senado Federal, 2001, p. 89.

${ }^{23}$ BEVILAQUA, Clóvis, Juristas philosophos. Imprenta: Bahia, Livraria Magalhães, 1897, p. 32. 
demonstra a forma de organização política e o senso prático do povo romano, um tratado precioso, afirmava Beviláqua. Diferente das concepções modernas do estado de natureza hobbesiano, os fundamentos da teoria ciceroniana buscava demonstrar que o homem não se reunia em sociedade com os demais pela falta de virtude ou pela fraqueza do estado natural, mas se reunia com seus semelhantes para tornar mais imperiosa à convivência.

Sobre as formas de governo, Beviláqua incorre em uma visão modernizante da política em Roma. Utiliza os conceitos de classe, burguesia, Estado e afirma em um determinado momento que Roma se transformou em uma monarquia constitucional onde se verificava o imperialismo $^{24}$ democrático de Roma. Essa é uma característica presente nos textos de Beviláqua, os conceitos e as idéias da modernidade são utilizados de forma anacrônica para explicar o passado, isto é, a sociedade romana. Dessa forma, verifica-se a influência das idéias modernas no pensamento do autor brasileiro, mesmo para explicar sociedades arcaicas utiliza categorias surgidas na modernidade.

No que diz respeito à obra de Cícero, Beviláqua discorda das críticas realizadas pelos juristas modernos a Cícero, inclusive as realizadas por Mommsen, que considerava a República como obra não filosófica. Beviláqua, um leitor assíduo de Cicero, faz uma síntese dos seis livros da República, o que indica que o autor manuseava e estava de posse dos livros. Já a obra $D e$ legibus, ele dispunha apenas dos três livros e alguns fragmentos. Esta obra é importante porque se verifica o desenvolvimento do conceito de lei e é nela que Cícero trata do direito natural. $\mathrm{O}$ aspecto realista e prático dos romanos se distanciava da concepção de Platão sobre as leis, a jurisprudência e a política. O que desperta interesse em Clóvis Beviláqua na obra de Cícero é o aspecto jurídico vinculado a filosofia, assim como os princípios do direito.

$\mathrm{O}$ autor brasileiro destaca que nenhum jurista em Roma conhecia mais a filosofia que Cicero e nenhum filósofo conhecia tão bem o direito quanto Cícero. É a ligação destes ramos do conhecimento que encanta Beviláqua. Assim como o aspecto universalista do direito, sobretudo, na obra De legibus, uma vez que o direito deriva da natureza humana, da vida em sociedade, seu fundamento é a universalidade.

\footnotetext{
${ }^{24}$ Sobre a confusão entre a termo de império e imperialismo, Ronaldo Poletti considera: "nada a estranhar na utilização equivocada do termo "império", cujo conceito deriva das fontes antigas, enquanto no contexto da modernidade ele foi cancelado, até mesmo, da memória dos juristas. [...]. Nem sempre as projeções históricas estão conforme ao modelo original e podem ter significados diferentes. Nessa linha se impõe o cotejo entre as idéias de Império e de Estado nacional, extremando-se, ainda, o imperialismo (hegemonia de um Estado) do Império (organização supranacional)". In: POLETTI, Ronaldo Rebello de Britto.Conceito jurídico de império. Editora Consulex. Brasília- DF, 2009, p. 20.
} 


\section{CONCLUSÃO}

Este artigo investiga o olhar atento de Clóvis Beviláqua aos manuais e livros dos autores modernos e dos autores clássicos de Roma. O historiador do direito Mario Bretone entende como necessário contextualizar a produção e o pensamento dos autores que estudamos, a fim de compreender a época em que viveram, os livros e professores que influenciaram seu pensamento, os amigos e inimigos ${ }^{25}$. Seguir esses rastros significa compreender melhor o contexto dos textos em que foram escritos e o processo de formação intelectual. O presente artigo pretendeu realizar, portanto, este exercício de história do direito tomando como referência o jurisconsulto Clóvis Beviláqua, redator da Codificação brasileira.

A pesquisa demonstra a riqueza e o aspecto universal do direito na obra de Clóvis Beviláqua antes da redação do Código Civil. Verificou-se marcas significativas do capítulo 9 e 10 da obra De legibus em sua produção jurídica. Uma consequiência desta leitura é a originalidade do pensamento de Clóvis Beviláqua no âmbito do direito comparado, cujo fundamento é o aspecto universalista. Nesse sentido, ele ressalta a idéia central de Cicero, para quem "o direito não pode deixar de possuir o caráter da universalidade; deve ser comum a todos os homens, porque a natureza humana é uma só." ${ }^{26}$ Nessa perspectiva, o direito não deriva da opinião, o direito é um só, é universal.

Beviláqua exaltava este enfoque internacionalista na obra ciceroniana, mas realizava críticas pontuais ao pensador. Em especial ao que diz respeito ao direito natural que na compreensão de Clóvis não correspondia mais a época moderna e ao caráter cientifico do direito no século XIX. Para ele, a natureza do direito não tem como fundamento a natureza humana, mas a razão. $\mathrm{O}$ aspecto racionalista do direito é exaltado em detrimento de conteúdos. Apesar de elogiar a importância de Cícero como jurista filósofo, se sobressai na obra de Clóvis Beviláqua a influência dos autores modernos, conforme ele mesmo afirmava: "o direito privado serve de norma à jurisprudência em nossos dias. É, pois, o estudo deste direito, que Savigny chamou direito romano atual, que nos interessa de perto." 27

No ano de 1893, Clóvis escreve na Memória histórica os acontecimentos e debates mais importantes que circulavam no Brasil no ano anterior e tinham sido debatidos na Faculdade de

\footnotetext{
${ }^{25}$ BRETONE, Mario. Diritto e tempo nella tradizione europea. EditoriLaterza, 2004, p. 80.

${ }^{26}$ BEVILÁQUA, Clóvis. Juristas philosophos. Imprenta: Bahia, Livraria Magalhães, 1897, p. 45.

${ }^{27}$ CAMPELLO, Manoel Netto Carneiro. Direito Romano. Preleções Expedidas em aula. Rio de Janeiro, Vol 1, 1929 p. 43
} 
Direito do Recife. Inicia o relato destacando o ambiente acadêmico e a importância dos docentes acompanharem a ciência contemporânea e aplicarem no ensino jurídico. Mostra eloquência no texto e cita fragmentos em alemão da obra de Schiller. No mês de julho, relata que a Faculdade de Direito havia sido convidada pela Real Academia de Jurisprudência de Madrid, para participar no Congresso Jurídico Ibérico-americano em comemoração a data de “descoberta da América".

Os professores eleitos para fazerem parte da Comissão que representaria a Faculdade de Direito do Recife foi Adelino, Barros Guimarães e Clóvis Beviláqua. Por motivo não mencionado, a comissão não participou do evento científico na Espanha. Essa fonte comprova o argumento que Clóvis era um professor que se interessava com o estudo comparativo com outros sistemas jurídicos. Era um professor e pesquisador ativo, inclusive, integrava a comissão de redação da Revista Acadêmica ${ }^{28}$, instrumento destinado a professores e a alunos para publicarem textos sobre temas e interesses.

Clóvis, na Memória histórica faz referência à necessidade de investigar as metodologias e ensino do direito na Europa. Diz Clóvis: "Publicações oficiais de categorias diversas, programas de ensino, memórias, relatórios das Faculdades de Direito de Paris, Berlim e Genebra já enriquecem nossa Biblioteca". Além disso, acrescenta que havia ocorriam trocas de conhecimento do que era produzido por professores europeus e os professores de direito do Recife, inclusive com a Itália ${ }^{29}$. Esses vestígios de informações são importantes, pois revelam como se consolidou o estudo do direto comparado e do direito romano na obra de Clóvis Beviláqua.

\section{REFERÊNCIAS}

AUGUSTO, J. Clovis Beviláqua e a Faculdade de Direito do Recife, 1959.

BEVILÁQUA, Clóvis. História da Faculdade de Direito do Recife. Rio de Janeiro, Francisco Alves, 1927, vol. II.

\footnotetext{
${ }^{28}$ No relato de José Augusto, aluno de Clóvis Beviláqua, a Revista Acadêmica começou a circular no ano de 1891 sob a direção de Clóvis Beviláqua, que publicava trabalhos e pesquisas realizadas pelos professores e alguns alunos laureados, de forma excepcional. Acrescenta que "quem quiser estudar a evolução do pensamento jurídico nacional, particularmente a que resultou da cooperação dos juristas recifenses, encontrará nas páginas daquela revista manancial abundantíssimo.”. In: AUGUSTO, J. Clovis Beviláqua e a Faculdade de Direito do Recife, 1959, p. 221

${ }^{29}$ Clóvis Beviláqua relata que o professor Barros Guimarães na Itália pretende aproximar relações científicas entre professores italianos e professores da Faculdade de Direito do Recife, criado redes de contato com importantes centros de referências que já são admirados pelos brasileiros. Identifica a relevância científica dos pesquisadores europeus, mas também demonstra a oportunidade de se tornarem conhecidos do outro lado do Atlântico.
} 
BEVILÁQUA, Clóvis. Resumo das Licçoes de Legislação Comparada sobre o Direito Privado. Recife: Typographia de F. P. Boulitreau, 1893.

BEVILÁQUA, Clóvis. Juristas philosophos. Imprenta: Bahia, Livraria Magalhães, 1897.

BRETONE, Mario. Diritto e tempo nella tradizione europea. EditoriLaterza, 2004.

CAMPELLO, Manoel Netto Carneiro. Direito Romano. Preleções Expedidas em aula. Rio de Janeiro, Vol 1, 1929.

CATALANO, Pierangelo. Diritto e persone. Studi su origine e attualità del sistema romano. G. Giappichelli Editore - Torino, 1990.

COSTA, Pietro. Passado: dilemas e instrumentos da historiografia. Revista da Faculdade de Direito UFPR, n. 47. Curitiba: UFPR, 2008.

DEMANGEAT, M. Charles. Coursélémentaraire de droit romain. Secondeedition. Paris, MarescoAiné, Libraire-editeur, 1866.

LOSANO, Mario G. La scuola di Recife e l'influenza tedesca sul diritto brasiliano. In: Giovanni Tarello. (org) Materiali per uma storiadella cultura giuridica. Vol. IV, Mulino, 1974

MEIRA, Silvio. Clóvis Beviláqua. Sua Vida. Sua Obra. Fortaleza: Edições Universidade Federal do Ceará, 1990, p. 346.

MELLUSO, M. La schiavitù nell'età giustinianea. Disciplina giuridica e rilevanzasociale, Paris 2000, PressesUniversitairesFranc-Comtoises, 2000.

OLIVEIRA, João Gualberto. Clóvis Centenario. São Paulo: Bentivegna, 1961.

PINTOR JUNIOR, João José. Curso elementar de direito romano. Recife, Typographia Economica, 1888.

POLETTI, Ronaldo Rebello de Britto. Conceito jurídico de império. Editora Consulex. Brasília- DF, 2009.

ROMERO, Silvio. O Brasil social e outros estudos sociológicos. Brasília: Senado Federal, 2001. 


\section{DADOS DA PUBLICAÇÃO}

Categoria: artigo submetido ao double-blind review.

Recebido em: 27/10/2020.

Aceito em: 10/07/2021. 